Dirāsāt: Jurnal Manajemen dan Pendidikan Islam, Vol. 6, No. 2, Desember 2020: 132-143. ISSN (Online): 2550-1038, ISSN (Print): 2503-3506. Website: journal.unipdu.ac.id/index.php/dirasat/index. Dikelola oleh Program Studi Manajemen Pendidikan Islam Program Pascasarjana Universitas Pesantren Tinggi Darul Ulum (Unipdu) Jombang Indonesia.

\title{
Pembentukan Karakter Santri Melalui Panca Jiwa Pondok Pesantren
}

\author{
Shalahudin Ismail, Mamun Zahrudin, Nurwadjah Ahmad, Andewi Suhartini \\ UIN Sunan Gunung Djati Bandung \\ Email: shalahudinismail75@gmail.com
}

\begin{abstract}
Abstrak: Penelitian ini bertujuan untuk mengkaji mengenai pembentukan karakter santri melalui Panca Jiwa Pondok di Pesantren Darul Muttaqien Parung Bogor. Metode yang digunakan adalah metode deskriptif, yaitu untuk mendeskripsikan dan menggambarkan fenomena yang ada di lapangan berupa fenomena yang bersifat ilmiah. Hasil penelitian menunjukkan bahwa pembentukan karakter santri di Pondok Pesantren Darul Muttaqien Parung Bogor dilandasi oleh Panca Jiwa Pondok. "Panca berarti lima, jiwa berarti ruh, pondok berarti kelembagaan pesantren." Lima ruh pesantren yaitu keikhlasan, kesederhanaan, kemandirian, ukhuwwah islāmiyyah dan kebebasan. Sehingga sebagai bagian dari proses pendidikan yang terpadu, maka setiap individu yang ikut memiliki tugas mencapai visi dan misi lembaga Pesantren Darul Muttaqien dituntut untuk mampu memahami nilai dari panca jiwa pondok sebagai sebuah nilai yang dijadikan pijakan dalam berorganisasi baik yang bergerak sebagai pendidik maupun pendukung lainya.

Kata kunci: Karakter, santri, pondok pesantren.
\end{abstract}

Abstract: This study aims to examine the character building of students through the five souls of the boarding school in Darul Muttaqien Parung, Bogor. The method used is descriptive method, namely to describe and describe phenomena that exist in the field in the form of scientific phenomena. The results showed that the formation of the character of the students in the Darul Muttaqien Parung Islamic boarding school, Bogor was based on the Panca Jiwa Pondok. "Panca means five, jiwa means spirit, pondok means institution of pesantren." The five spirits of the pesantren, namely sincerity, simplicity, independence, ukhuwwah islämiyyah and freedom. So that as part of an integrated educational process, every individual who shares the task of achieving the vision and mission of the Darul Muttaqien Islamic boarding school is required to be able to understand the values of the five souls of the pondok as a value that is used as a foothold in organizations both as educators and as other supporters.

Keywords: Character, students, Islamic boarding school.

\section{Pendahuluan}

Pondok pesantren sebagai lembaga pendidikan Islam tertua di Indonesia, telah berkembang sejak masa penyebaran Islam dan memiliki konstribusi dalam mencerdaskan kehidupan masyarakat. Pondok pesantren diharapkan tidak hanya berkemampuan dalam pembinaan pribadi muslim yang islami, tetapi juga mampu mengadakan perubahan dan perbaikan sosial kemasyarakatan. Pengaruh pesantren sangat positif bila alumninya telah kembali ke masyarakat dengan membawa berbagai perubahan dan perbaikan bagi kehidupan masyarakat sekitarnya. ${ }^{1}$ Dalam Peraturan Pemerintah No. 55 tahun 2007 tentang pendidikan pesantren menyebutkan bahwa tujuan pendidikan pesantren adalah menanamkan keimanan dan ketakwaan kepada Allah SWT, akhlak

\footnotetext{
${ }^{1}$ Elfridawati Mai Dhuhani, "Manajemen Pondok Pesantren: Studi Pengelolaan Santri Muallaf di Pondok Pesantren Al Anshar Ambon," Jurnal Fikratuna 9, no. 1 (2018): 54-70.
} 
mulia, serta tradisi pesantren untuk mengembangkan kemampuan, pengetahuan, dan keterampilan sehingga menjadi ahli ilmu agama Islam dan menjadi muslim yang memiliki keterampilan untuk membangun kehidupan islami di masyarakat. ${ }^{2}$

Di antara kebijakan pemerintah dalam upaya mempercepat pemerataan dan aksesibilitas Wajar Dikdas di antaranya adalah memperluas penyelenggaraan pendidikan yang melibatkan pondok pesantren. Kebijakan tersebut memberikan kewenangan kepada pondok pesantren untuk menyelenggarakan pendidikan dasar (ulā dan wusțā) dalam konteks program Wajar Dikdas melalui Surat Kesepakatan Bersama (SKB) antara Menteri Pendidikan Nasional dan Menteri Agama Nomor: 1/U/KB/2000 dan Nomor: MA/86/2000 tentang Pondok Pesantren sebagai Pola Wajib Belajar Pendidikan Dasar Sembilan Tahun. SKB tersebut telah ditindaklanjuti dengan Keputusan Bersama Dirjen Pembinaan Kelembaga- an Agama Islam Departemen Agama de- ngan Dirjen Pendidikan Dasar dan Menengah Departemen Pendidikan Nasional Nomor: E/83/2000 dan Nomor: 166/C/Kep/ DS/2000 tentang Pedoman Pelaksanaan Pondok Pesantren sebagai Pola Wajib Belajar Pendidikan Dasar. ${ }^{3}$

Presiden Jokowi mengatakan bahwa pesantren sebagai pendukung utama pembentukan karakter Bangsa. Karena pembentukan pendidikan agama dan karakter bagi siswa sangat cocok dilakukan di sekolah yang menggunakan sistem berbasis pesantren. Karena berkaitan dengan pembentukan etika, moral, dan akhlak yang kedepannya nanti siswa ini akan menjadi generasi penerus bangsa. Begitupun pernyataan Gubernur Sulawesi Tengah, Longki Djanggola bahwa pondok pesantren adalah pendidikan tertua di Indonesia bahkan sebelum Indonesia merdeka, diharapkan mampu menjadi panutan dan teladan bagi sitem pendidikan karakter yang sedang menjadi sentral pendidikan sekarang. ${ }^{4}$ Namun, berdasarkan berbagai peristiwa yang terjadi, bahwasanya moral anak bangsa telah merosot begitu tajamnya. Hal ini disebabkan antara lain karena banyak sekolah di Indonesia hanya menjadi tempat untuk memindahkan pengetahuan baik pengetahuan secara umum maupun etika, dan belum sampai pada taraf pembentukan moral dan etika (character building). ${ }^{5}$

Di sinilah fungsi pondok pesantren sebagai agen implementasi pendidikan karakter secara efektif tidak hanya mengajarkan tentang nilai-nilai agama saja, melainkan juga diajarkan tentang nilai etika, nilai moral, nilai estetika dan nilai seni yang membawa santri menjadi manusia yang berkepribadian sempurna.

\footnotetext{
${ }^{2}$ Djamaluddin Perawironegoro, "Manajemen Asrama di Pesantren," Tadbir: Jurnal Studi Manajemen Pendidikan 3, no. 2 (2019): 129-144.

${ }^{3}$ Kamin Sumardi, "Potret Pendidikan Karakter di Pondok Pesantren Salafiah," Jurnal Pendidikan Karakter 0, no. 3 (2013): 280-291.

${ }^{4}$ Nizarani, "Manajemen Pendidikan Karakter Sekolah Islam Terpadu Berbasis Pesantren," Prosiding Seminar Nasional Pendidikan Program Pascasarjana Universitas PGRI Palembang (2019): 1134-1147.

${ }^{5}$ Imam Syafe'i, "Pondok Pesantren: Lembaga Pendidikan Pembentukan Karakter," AlTadzkiyyah: Jurnal Pendidikan Islam 8, no. 1 (2017): 61.
} 
Lickona menekankan tiga komponen dalam pendidikan karakter, yaitu (1) moral knowing atau pengetahuan tentang moral, (2) moral feeling atau perasaan tentang moral, dan (3) moral action atau perbuatan moral. Hal ini diperlukan agar santri mampu memahami, merasakan, dan mengerjakan sekaligus nilai-nilai kebajikan. Tiga nilai tersebut yang selalu diajarkan dan ditekankan kepada para santri di pondok pesantren. ${ }^{6}$ Kekhasan pesantren adalah lembaga pendidikan agama dengan kiai sebagai tokoh sentralnya dan masjid sebagai pusat lembaganya. Sejalan dengan itu, panggilan yang mendorong kiai mengajarkan pengetahuan agamanya kepada santri adalah rasa wajib berbakti kepada Allah SWT Begitu pula halnya dorongan yang menggerakkan hati para santri dalam menuntut ilmu. ${ }^{7}$ Hakekat pondok pesantren sejatinya terletak pada isi dan jiwa (ruh)nya, bukan pada kulitnya karena jiwa yang menguasai suasana kehidupan pondok pesantren itulah yang dibawa oleh para santri sebagai bekal pokok dalam kehidupannya di masyarakat. Dan jiwa pondok pesantren inilah yang harus sentiasa dihidupkan, dipelihara dan dikembangkan dengan sebaik-baiknya. ${ }^{8}$

Pembentukan karakter lewat pesantren dimulai dengan pembiasaanpembiasaan yang positif seperti, pola hidup sederhana, menumbuhkan rasa persaudaraan dan persahabatan yang erat antar santri sehingga kecil kemungkinan terjadi konflik dan perkelahian. Krisis moral dan akhlak yang baru melanda di tanah air kita akhir-akhir ini sebenarnya bisa diatasi dengan lembaga pendidikan yang sudah ada yaitu lewat pendidikan pesantren melalui pembiasaan yang positif disegala aspek kehidupan santri. ${ }^{9}$ Yusuf dalam penelitiannya menyatakan bahwa pendidikan karekter bukan hanya berhubungan dengan benar atau salah, tetapi bagaimana menanamkan kebiasaan (habituation) dalam kehidupan sehari-hari, sehingga santri memiliki kesadaran, kepekaan, kepedulian, dan komitmen untuk menerapkan kebijakan dalam kehidupannya. ${ }^{10}$ Selanjutnya Sri Wahyuni Tanshzil mengatakan bahwa Pondok Pesantren sebagai lembaga pendidikan nonformal sarat dengan pendidikan nilai, baik nilai agama maupun nilai-nilai luhur bangsa, menjadi sebuah lembaga yang sangat efektif dalam mengembangkan pendidikan karakter. ${ }^{11}$ Lebih lanjut Fifi Nofiaturrahmah menyatakan, pondok pesantren sebagai salah satu jenis lembaga pendidikan Islam di Indonesia, telah terbukti

\footnotetext{
${ }^{6}$ St. Rodliyah, "Manajemen Pondok Pesantren Berbasis Pendidikan Karakter," Jurnal Cendekia 12, no. 2 (2014): 299-314.

${ }^{7}$ Dedy Susanto, "Manajemen Pengembangan Sumber Daya Santri Berbasis Teknologi Tepat Guna di Pondok Pesantren," Jurnal Ilmu Dakwah 37, no. 2 (2017): 247-283.

${ }^{8}$ Ahmad Suradi, "Dampak Transformasi Sistem Pendidikan Pesantren Terhadap Penanaman Jiwa Keikhlasan Santri," Jurnal At-Ta'dib 13, no. 1 (2018): 49-66.

${ }^{9}$ Nur Hidayat, "Implementasi Pendidikan Karakter Melalui Pembiasaan di Pondok Pesantren Pabelan," JPSD : Jurnal Pendidikan Sekolah Dasar 2, no. 1 (2016): 128-145.

${ }^{10}$ M Yusup, "Manajemen Pendidikan Karakter Berbasis Pondok Pesantren Darussyifa Al-Fithroh Yaspida Sukabumi," Jurnal Tadbir Muwahhid 2, no. April (2018): 11-24.

${ }^{11}$ Sri Wahyuni Tanshil, "Model Pembinaan Pendidikan Karakter pada Lingkungan Pondok Pesantren dalam Membangun Kemandirian dan Disiplin Santri," Penelitian Pendidikan 13, no. 2 (2012): 1-18.
} 
secara empiris mampu mengembangkan santri dari berbagai aspek, meliputi kemampuan intelektual, emosional dan pembentukan watak religius, sehingga lahirlah output pesantren yang memiliki pengetahuan dan akhlak karimah atau berkarakter. Keberhasilan pesantren dalam membentuk karakter santri karena pendidikan pesantren siswa diasramakan di pondok dalam bimbingan dan pengawasan kiai, adanya wibawa dan keteladanan kiyai sebagai pemimpin pesantren dan suasana religius dalam pembelajaran di pesantren. ${ }^{12}$

Bersumber dari pemikiran tersebut, peneliti tertarik untuk mengkaji lebih dalam lagi terhadap pembentukan karakter melalui Panca Jiwa Pondok di pesantren Darul Muttaqien Parung Bogor. Adapun metode yang digunakan dalam penelitian ini adalah metode deskriptif yang bertujuan untuk mendeskripsikan dan menggambarkan fenomena yang ada di lapangan yaitu fenomena yang bersifat ilmiah.

\section{Tinjauan Umum tentang Karakter}

Dalam Kaтиs Umum Bahasa Indonesia, karakter diartikan sebagai "tabiat, watak, sifat-sifat kejiawaan, akhlak, atau budi pekerti yang membedakan seseorang dengan orang lain." Dengan kata lain karakter adalah budi pekerti atau akhlak yang dimiliki oleh seseorang. ${ }^{13}$ Lebih jauh karakter dapat dimaknai sebagai nilai dasar yang membangun pribadi seseorang, terbentuk baik karena pengaruh hereditas maupun pengaruh lingkungan, yang membedakannya dengan orang lain, serta diwujudkan dalam sikap dan perilakunya dalam kehidupan sehari-hari. ${ }^{14}$ Secara istilah terdapat dua pengertian, pertama karakter menunjukkan bagaimana seseorang bertingkah laku. Apabila seseorang berperilaku tidak jujur, kejam, atau tidak rukun, maka orang tersebut memanifulasikan karakter jelek. Sebaliknya apabila seseorang berperilaku jujur, suka menolong, maka orang tersebut memanifulasikan karakter mulia. Kedua, istilah karakter erat kaitannya dengan personality. Seseorang disebut orang berkarakter kalau tingkah lakunya sesuai dengan kaidah moral. ${ }^{15}$ Sementara Lickona mengemukakan bahwa karakter terdiri atas tiga bagian yang saling terkait, yaitu pengetahuan tentang moral (moral knowing), perasaan moral (moral feeling), dan perilaku bermoral (moral behavior). Karakter yang baik terdiri atas mengetahui kebaikan, mencintai atau menginginkan kebaikan, dan melakukan kebaikan. Cara membentuk karakter yang efektif adalah dengan melibatkan ketiga aspek tersebut.

\footnotetext{
${ }^{12}$ Fifi Nofiaturrahmah, "Metode Pendidikan Karakter di Pesantren," Jurnal Pendidikan Agama Islam 11, no. 2 (2017): 201-216.

${ }^{13}$ Muhammad Minan Zuhri, "Pelaksanaan Pendidikan Karakter Melalui Sistem Pendidikan Pesantren" (2019): 54-70.

${ }^{14} \mathrm{H}$ A Rodli Makmun, "Pembentukan Karakter Berbasis Pendidikan Pesantren," Jurnal Cendekia 12, no. 2 (2014): 211-238.

${ }^{15}$ Sofyan Sauri, Nilai Kearifan Pesantren, ed. Mohamad Zaka Al-Farisi (Bandung: Rizqi Press, 2017).
} 
Dalam Pedoman Pelaksanaan Pendidikan Karakter yang diterbitkan oleh Kementerian Pendidikan Nasional tahun 2011, disebutkan bahwa pendidikan karakter adalah pendidikan nilai, pendidikan budi pekerti, pendidikan moral, pendidikan watak yang bertujuan mengembangkan kemampuan peserta didik agar mampu memberikan keputusan baik-buruk, memelihara apa yang baik dan mewujudkan kebaikan itu dalam kehidupan sehari-hari dengan sepenuh hati. ${ }^{16}$ Berdasarkan pengertian tersebut, dapat dimaknai bahwa pembentukan karakter merupakan proses bimbingan melalui suri teladan pendidikan yang berorientasi pada penanaman nilai-nilai kehidupan yang di dalamnya mencakup nilai agama, budaya, etika, dan estetika menuju pembentukan pribadi peserta didik yang memiliki kecerdasan spiritual keagamaan, pengendalian diri, kepribadian yang utuh, berakhlak mulia, serta keterampilan yang diperlukan dirinya, masyarakat, dan negara.

Kiai merupakan penggerak dalam pembentukan karakter warga pondok pesantern atau yang sering disebut dengan santri, hal ini sejalan dengan tujuan pendidikan nasional yang mana bahwa sistem pendidikan pada pondok pesantren saat ini memang mengacu pada sistem pendidikan Nasional yang berbunyi, "pendidikan nasional berfungsi mengembangkan kemampuan dan membentuk watak serta peradaban bangsa yang bermartabat dalam rangka mencerdaskan kehidupan bangsa." ${ }^{17}$ Tujuannya adalah untuk mengembangkan nilai-nilai yang membentuk karakter bangsa, yaitu Pancasila, meliputi: (1) mengembangkan potensi peserta didik agar menjadi manusia yang berhati baik, berperilaku baik, dan berpikiran baik; (2) membangun bangsa yang berkarakter Pancasila; dan (3) mengembangkan potensi agar mempunyai sifat percaya diri, bangga terhadap Negaranya dan bersikap baik kepada orang lain. ${ }^{18}$

Ratna Megawangi menyatakan, terdapat sembilan pilar karakter yang layak diajarkan kepada peserta didik dalam konteks pendidikan karakter, yakni, (1) cinta Tuhan dan segenap ciptaan-Nya (love Allah, trust, reverence, loyality); (2) kemandiaran dan tanggungjawab (responsibility, excellence, self reliance, discipline); (3) kejujuran dan amanah, bijaksana (trustworthiness, reliability, honesty); (4) hormat dan santun (respect, courtesy, obedience), (5) Dermawan, suka menolong, dan gotong-royong (love, compassion, caring, empathy, generousity, moderation, cooperation); (6) percaya diri, kreatif, pekerja keras (confidence, assertiveness, creativity, determination, and enthusiasm); (7) kepemimpinan dan keadilan (justice, fairness, mercy, leadership); (8) baik dan rendah hati (kindness, friendliness, humanity, modesty); (9) toleransi, kedamaian, dan kesatuan (tolerance, flexibility, peacefulness). ${ }^{19}$

\footnotetext{
${ }^{16}$ A Muchaddam Fahham, "Pendidikan Karakter di Pesantren," Jurnal Aspirasi 4, no. 1 (2013): 29-45.

${ }^{17}$ Mohammad Masrur, "Figur Kyai dan Pendidikan Karakter di Pondok Pesantren," Tarbawiyah Jurnal Ilmiah Pendidikan 14, no. 02 (2018): 272-282.

${ }^{18}$ Fauzan, "Pendidikan Karakter Berbasis Pesantren: Studi Kasus di SMP Puncak Darus Salam Pamekasan," Empirisma 24, no. 2 (2015): 275-284.

${ }^{19}$ Makmun, "Pembentukan Karakter Berbasis Pendidikan Pesantren."
} 
Arifin menyatakan, bahwa rumusan tujuan pondok pesantren adalah sebagai berikut. Pertama, tujuan umum, yaitu membentuk mubalig-mubalig Indonesia berjiwa Islam yang bertaqwa, mampu baik rohaniah maupun jasmaniah dengan mengamalkan ajaran agama Islam bagi kepentingan kebahagian hidup diri sendiri, keluarga, masyarakat dan bangsa serta Negara Indonesia. Kedua, tujuan khusus, yaitu memberikan keterampilan, olah raga dan kesehatan kepada santri; memberikan pengertian keagamaan melalui praktek ajaran ilmu agama Islam; mengembangkan sikap beragama melalui praktik-praktik ibadah; mewujudkan persaudaran dalam pondok pesantren dan sekitarnya; dan membimbing suasana hidup keagamaan dalam pondok pesantren sebaik mungkin sehingga menarik pada jiwa anak didiknya (santri) ${ }^{20}$

Para pakar pendidikan berpandangan bahwa pesantren adalah pionir pendidikan karakter di Indonesia. Dalam suatu kesempatan misalnya Kepala Badan Pusat Penelitian dan Pengembangan (Balitbang), Kementerian Pendidikan Nasional (Kemdiknas), Khairil Anwar Notodiputro, mengatakan bahwa pesantren merupakan "tambang emas" dan contoh pengembangan model pendidikan karakter di Indonesia. Pesantren merupakan pola pendidikan yang konsen dalam pengembangan karakter, karena karakter menjadi variabel terpenting dalam pola pendidikan yang dikembangkan di pesantren. Nilai-nilai yang diajarkan pesantren menurutnya adalah budaya ikhlas, kesederhanaan, kemandirian, ukhuwwah islämiyyah, ukhuwwah wațaniyyah atau persaudaraan kebangsaan, mempertahankan warisan budaya tradisonal dan bercorak lokal. ${ }^{21}$ Dengan demikian pondok pesantren memiliki konstribusi penting dalam meningkatkan kualitas sumber daya manusia. Di mana umumnya diketahui, bahwa pondok pesantren sebenarnya tidak hanya memberikan pengetahuan dan keterampilan teknis semata, tetapi jauh lebih penting adalah menanamkan nilainilai agama dan sikap. Sejarah pendidikan pesantren dilandasi atas hubungan yang berarti antara manusia dengan Allah SWT (habl min allāh) dimana hubungan tersebut mempunyai arti menghasilkan keagungan dan keindahan. Ibadah yang dijalani oleh semua ustaz dan santri di pondok pesantren diutamakan dalam hal mencari ilmu, mengelola pelajaran, mengembangkan kegiatan bersama santri dan masyarakat dan mengembangkan diri.

\section{Pembentukan Karakter Santri Melalui Panca Jiwa Pondok di Pesantren Darul Muttaqien}

Pesantren adalah salah satu institusi yang unik dengan ciri-ciri khas yang sangat kuat dan lekat. Peran yang diambil adalah upaya-upaya pencerdasan bangsa yang telah turun temurun tanpa henti. Pesantrenlah yang memberikan pendidikan pada masa-masa sulit, masa perjuangan melawan kolonial dan merupakan pusat studi yang tetap survive sampai masa kini. Tujuan pendidikan

\footnotetext{
${ }^{20}$ Wiwin Fitriyah, Abd Hamid Wahid, dan Chusnul Muali, "Eksistensi Pesantren dalam Pembentukan Kepribadian Santri," Palapa 6, no. 2 (2018): 155-173.

${ }^{21}$ Fahham, "Pendidikan Karakter di Pesantren."
} 
pesantren menurut Zamakhsyari Dhofier, bukanlah untuk mengejar kepentingan kekuasaan, uang dan keagungan duniawi, tetapi ditanamkan kepada mereka bahwa belajar adalah semata-mata kewajiban dan pengabdian kepada Tuhan. Pembentukan karakter harus dilakukan secara sistematis dan berkesinambungan yang melibatkan aspek knowledge, feeling, loving dan action. Pembentukan karakter dapat diibaratkan sebagai pembentukan seseorang menjadi body builder (binaragawan) yang memerlukan "latihan otototot akhlak" secara terus-menerus agar menjadi kokoh dan kuat. ${ }^{22}$ Sistem pendidikan karakter yang ada di pesantren lebih menitikberatkan pada penguatan kualitas internal atau "introvert", daripada pengembangan eksternal atau "extrovert" baik dalam didaktik maupun di dalam sistem serta metode pengajaran dan pendidikannya. Untuk mengimbangi berbagai nilai baik dari dalam maupun di luar diperlukan pendidikan karakter yang memadukan keduanya. ${ }^{23}$

Salah satu pondok pesantren di Indonesia, yang sangat peduli tehadap pembentukan karakter santri dan mempunyai ciri khas tersendiri dalam mendidik santrinya adalah pondok pesantren Darul Muttaqien Parung Bogor. Keberhasilan pondok pesantren Darul Muttaqien Parung Bogor menjadi salah satu pondok pesantren ternama di Jawa Barat bukan terjadi begitu saja. Dia meyakini suksesnya pengembangan pendidikan karakter di pondok pesanren Darul Muttaqien Parung Bogor yang didirikan sejak tahun 1988 itu tak lepas dari pengelolaan manajemen yang baik. Berdasarkan hasil wawancara dengan salah satu pengasuh pondok bahwa pembentukan karakter santri di pondok pesantren Darul Muttaqien Parung Bogor dilandasi oleh Panca Jiwa Pondok, setiap nilai dari panca jiwa tersebut memiliki indikator dan penjelasanya. Sebagai bagian dari proses pendidikan yang terpadu maka setiap individu yang ikut memiliki tugas mencapai visi dan misi lembaga pesantren Darul Muttaqien dituntut untuk mampu memahami nilai dari panca jiwa pondok sebagai sebuah nilai yang dijadikan pijakan dalam berorganisasi baik yang bergerak sebagai pendidik maupun pendukung lainya.

\section{Jiwa Keikhlasan}

Jiwa keikhlasan menurut salah satu pengasuh pondok maksudnya melakukan segala aktivitas kehidupan di dunia ini tidak didorong oleh keinginan untuk memperoleh keuntungan (sepi ing pamrih). Ikhlas berarti pasrah dan menerima apapun yang terjadi, karena hidup itu disutradarai langsung oleh Allah. Sehingga bentuk apapun perintahnya kalau itu baik berarti itu perintah dari Allah dengan sebuah perantara. Dalam hal ini meliputi segenap kehidupan di pesantren. Contohnya adalah kiai ikhlas dalam mengajar, karena kiai telah

\footnotetext{
${ }^{22}$ Syafe'i, "Pondok Pesantren: Lembaga Pendidikan Pembentukan Karakter."

${ }^{23}$ Sopidi, "Integrasi Modal Sosial dan Budaya dalam Pengembangan Nilai-Nilai Pendidikan Karakter di Pondok Pesantren Modern As-Sakinah Sliyeg Indramayu," Holistik 15, no. 2 (2014): 287-308.
} 
mengorbankan segalanya baik berupa harta maupun tenaga untuk menjalankan amanat dari gurunya. Oleh karena itu, jiwa keikhlasan dengan dasar seperti itu membuat kiai dalam melakukan pengajaran terhadap santrinya tidak mengharapkan gaji dari pondok, tetapi justru ikhlas mengorbankan hartanya untuk kepentingan pondok. Santri ikhlas dalam belajar, maksudnya menerima segala bentuk apapun yang ada dalam proses pendidikan di pondok pesantren. Sehingga setelah terjun di masyarakat, tidak memiliki harapan-harapan duniawi melainkan hanya mengharapkan imbalan dari Allah. Para ustaz-ustazah ikhlas membantu pondok dalam memberikan pengajaran terhadap santri, bukan berarti tidak ada gaji yang didapat. Ikhlas disini maksudnya memprioritaskan kinerja dengan baik dan semata-mata hanya untuk ibadah, kemudian dari kinerja itu mampu mensejahterakan kebutuhan hidupnya.

Konsep jiwa keikhlasan dapat menghadirkan niat hanya karena Allah dengan upaya kuat dan sungguh-sungguh dalam berpikir, bekerja, dan berbuat semata-mata hanya mencari ridha Allah. keikhlasan disini tidak hanya pasrah dan tidak melakukan apapun, tetapi ada tujuan-tujuan yang memiliki manfaat. Apabila jiwa keikhlasan ini telah terbentuk, maka akan terbangunlah jiwa kesederhanaan, yang dimaksudkan bukan karena kemelaratan atau kemiskinan, tetapi mengandung unsur kekuatan dan ketabahan seorang hamba dan mampu menguasai diri dalam menghadapi perjuangan hidup dengan segala kesulitan. Hingga dibalik kesulitan itu akan tercapailah jiwa yang besar, berani maju terus dalam menghadapi perjuangan hidup, dan tidak menyerah dalam segala keadaan.

\section{Jiwa Kesederhanaan}

Jiwa kesederhanaan bukan berarti pasif dan bukan berarti karena kemiskinan, tetapi mengandung unsur kekuatan dan ketabahan hamba, dan memiliki kemampuan dalam menghadapi perjuangan hidup dengan segala kesulitannya. Maka dibalik kesusahan itu akan tercapailah jiwa besar, berani maju terus, pantang mundur dalam segala situasi. Di sinilah akan terbentuk karakter yang kuat sebagai syarat bagi suksesnya perjuangan dalam segala kehidupan. Dalam aturan Pesantren Darul Muttaqien, tidak boleh membawa berbagai perhiasan yang tidak diperlukan atau membawa uang jajan terlalu banyak karena akan boros. Sikap boros berarti melakukan sesuatu tidak sesuai dengan kebutuhan atau melebihi kebutuhan yang seharusnya. Sikap boros berarti memenuhi sesuatu sesuai dengan keinginan dan nafsu semata. Nilai inilah yang dimaksud dengan kesederhanaan dalam panca jiwa pondok tersebut.

Dalam hal pelaksanaannya, pondok pesantren Darul Muttaqien memberikan konsep keseragaman dalam hal apapun, seperti halnya dalam berpakaian. Ketika santri memakai pakaian yang seragam, hal tersebut dapat membuat tidak ada perbedaan antara santri kaya maupun miskin. Tidak memunculkan sikap riya, takabbur, dan ujub, sehingga tujuan pondok tentang hidup sederhana dapat terwujud yang kemudian akan melahirkan jiwa kemandirian. 


\section{Jiwa Kemandirian}

Pondok pesantren Darul Muttaqien mendefinisikan kemandirian dengan kemampuan untuk menolong dirinya sendiri tidak saja dalam arti bahwa santri sanggup mengurus kepentingannya sendiri, tetapi pondok pesantren itu sendiri sebagai lembaga pendidikan juga harus sanggup berdikari. Sehingga baik santri maupun lembaga tidak menyandarkan kelangsungan hidupnya kepada bantuan dan belas kasihan pihak lain. Pimpinan pondok pesantren Darul Muttaqien selalu mengembangkan semboyan bahwa "ayam saja bisa mandiri untuk mencari makan setiap hari, apalagi menusia." Santri tidak boleh kalah dengan ayam. Kemandirian pesantren sebagai lembaga pendidikan tidak perlu ditanyakan lagi. Sebab pesantren sejak berdirinya sudah mandiri dengan biaya swadaya kiai dan masyarakat. Pesantren tidak pernah menyandarkan dirinya terhadap berbagai bantuan dari pemerintah, lain lagi jika diberi. Bahkan dalam perjalanan sejarahnya, berdirinya pesantren sangat dikucilkan oleh pemerintah dan dicurigai oleh bangsa penjajah. Tidak mengherankan jika para kiai, ulama dan santri saat itu justru banyak yang menjadi korban dan dibunuh oleh para penjajah dan penghianat Islam. Kemandirian adalah persoalan mental.

Pribadi yang mandiri berarti pribadi yang punya tekad untuk selalu berusaha semaksimal mungkin, tidak mudah putus asa, tidak bermental pengemis, dan selalu ingin membantu orang lain. Islam mengajarkan umatnya untuk mandiri dan bekerja. Nilai kemandirian yang dikembangkan di Darul Muttaqien juga dalam pengertian selalu berorientasi untuk membantu orang lain, bukan untuk berharap bantuan dari orang lain. Dalam bahasa lain kemandirian adalah mental to give bukan mental to have. Sebab kemandirian selain ditandai oleh kemampuan untuk mengatur dan menolong dirinya sendiri juga bercirikan mampu menolong orang lain. Dari sinilah nilai kemandirian dikembangkan dan diaplikasikan dalam program- program konkret.

\section{Jiwa Ukhuwah Islämiyyah}

Berdasarkan hasil wawancara dengan pengasuh pondok pesantren, bahwa ukhuwah islamiah itu merupakan salah satu tujuan dari hidup manusia, yaitu menciptakan kedamaian dan kebahagiaan. Sebab itu, santri harus terus dilatih untuk saling menjaga satu sama lain demi menciptakan kedamaian tersebut. Sehingga ukhuwah yang dilakukan, bukan saja dilaksanakan selama dalam pondok pesantren, akan tetapi juga mampu memberikan pengaruh dalam masyarakat sepulang dari pondok. Ukhuwah itu dibentuk agar nantinya santri memiliki kemampuan untuk beradaptasi dengan baik kepada semua orang dan dapat menciptakan hubungan yang harmonis antar umat beragama.

Lebih lanjut dikatakan bahwa semangat persaudaraan yang sangat akrab dapat dirasakan bersama baik susah maupun senang, yang tentunya terdapat banyak nilai keagamaan yang melegitimasinya. Interaksi yang dilakukan di pondok pesantren Darul Muttaqien baik antar santri, santri dengan masyarakat, dan santri dengan alumni merupakan upaya pondok pesantren dalam 
membentuk jiwa ukhuwah, yang kemudian terjalinlah hubungan yang baik . oleh sebab itu, jika jiwa ukhuwah dapat terbentuk, maka santri akan memiliki akhlak yang wasațiyah dan insāniyah yang memiliki sebuah risalah dan misi penting untuk memerdekan, membahagiakan, menghormati, dan memuliakan manusia.

\section{Jiwa Kebebasan}

Jiwa kebebasan di pondok pesantren Darul Muttaqien maksudnya yaitu kebebasan dalam berpikir dan berbuat, kebebasan dalam menentukan masa depannya, dan kebebasan dalam memilih jalan hidup di masyarakat kelak. Juga diartikan sebagai kebebasan dalam menentukan segala hal agar fokus pasrah kepada Allah. Sehingga ketika bebas melakukan sesuatu yang berdampak baik bagi diri sendiri dan orang lain, maka hal itu secara otomatis Allahlah yang memberikan jalan yang baik kepada kita. Jiwa kebebasan tersebut memiliki keterkaitan dengan jiwa keikhlasan. Sebab dengan memiliki jiwa keikhlasan, maka seseorang dapat bebas melakukan sesuatu kepada dirinya dengan penuh kepasrahan, sehingga kebebasannya itu atas bimbingan Allah. Menurut peneliti, jiwa kebebasan ini memiliki implikasi yang sangat bagus dalam pembentukan karakter santri. Sehingga santri tidak hanya lulus dengan keilmuan yang dipelajari selama di pondok pesantren, juga memiliki kemampuan dalam menerima berbagai hal yang menyangkut kebebasan berpendapat. Santri diberikan kebebasan untuk mengembangkan diri sesuai talenta yang dimiliki, bebas untuk mengekpresikan diri melalui seni dan karyakarya, kebebasan untuk menentukan pilihan setelah selesai dari Darul Muttaqien, kebebasan untuk memilih jurusan yang disukai, kebebasan untuk memilih program-program ekstrakulikuler yang disediakan di lembaga. Kesemuanya bentuk kebebasan itu harus dalam bimbingan para guru pembimbing. Dan yang lebih penting lagi bahwa semua kebebasan yang dikembangkan adalah yang positif yang didasarkan oleh ajaran Islam.

Bersumber dari hasil analisis dan pembahasan pada penelitian ini, maka dapat diketahui bahwa pondok pesantren merupakan sistem pendidikan Islam tertua khas Indonesia, mempunyai ciri dan karakteristik yang berbeda dengan lembaga pendidikan Islam lainnya pada umumnya. Sebagai lembaga Pendidikan Islam, pesantren mempunyai tujuan yang dirumuskan dengan jelas sebagai acuan program-program pendidikan yang diselenggarakan. Tujuan dari pembentukan karakter melalui panca jiwa pondok di pesantren Darul Muttaqien agar santri memiliki jiwa keikhlasan, kesederhanaan, kemandirian, ukhuwah islamiah, dan jiwa kebebasan yang kelak dapat diaplikasikan dalam kehidupannya di masyarakat.

\section{Kesimpulan}

Berdasarkan ulasan di atas, bahwa pondok pesantren sebagai agen implementasi pendidikan karakter secara efektif tidak hanya mengajarkan 
tentang nilai-nilai agama saja, melainkan juga diajarkan tentang nilai etika, nilai moral, nilai estetika dan nilai seni yang membawa santri menjadi manusia yang berkepribadian sempurna. Pembentukan karakter santri di pondok pesantren Darul Muttaqien Parung Bogor dilandasi oleh Panca Jiwa Pondok, yang memiliki makna "panca berarti lima, jiwa berarti ruh, pondok berarti kelembagaan pesantren." Lima ruh pesantren yang dimaksud adalah keikhlasan, kesederhanaan, kemandirian, ukhuwwah islamiah dan kebebasan, agar kelak dapat diaplikasikan oleh santri dalam kehidupannya di masyarakat.[]

\section{Daftar Pustaka}

Dhuhani, Elfridawati Mai. "Manajemen Pondok Pesantren: Studi Pengelolaan Santri Muallaf di Pondok Pesantren Al Anshar Ambon." Jurnal Fikratuna 9, no. 1 (2018): 54-70.

Fahham, A Muchaddam. "Pendidikan Karakter di Pesantren." Jurnal Aspirasi 4, no. 1 (2013): 29-45.

Fauzan, Fauzan. "Pendidikan Karakter Berbasis Pesantren: Studi Kasus di SMP Puncak Darus Salam Pamekasan.” Empirisma 24, no. 2 (2015): 275-284.

Fitriyah, Wiwin, Abd Hamid Wahid, and Chusnul Muali. "Eksistensi Pesantren dalam Pembentukan Kepribadian Santri.” Palapa 6, no. 2 (2018): 155173.

Hidayat, Nur. "Implementasi Pendidikan Karakter Melalui Pembiasaan di Pondok Pesantren Pabelan.” JPSD : Jurnal Pendidikan Sekolah Dasar 2, no. 1 (2016): 128-145.

Makmun, H A Rodli. "Pembentukan Karakter Berbasis Pendidikan Pesantren." Jurnal Cendekia 12, no. 2 (2014): 211-238.

Masrur, Mohammad. "Figur Kiai dan Pendidikan Karakter di Pondok Pesantren." Tarbawiyah Jurnal Ilmiah Pendidikan 14, no. 02 (2018): 272282.

Muhammad Minan Zuhri. "Pelaksanaan Pendidikan Karakter Melalui Sistem Pendidikan Pesantren" (2019): 54-70.

Nizarani, Nizarani. "Manajemen Pendidikan Karakter Sekolah Islam Terpadu Berbasis Pesantren." Prosiding Seminar Nasional Pendidikan Program Pascasarjana Universitas PGRI Palembang (2019): 1134-1147.

Nofiaturrahmah, Fifi. "Metode Pendidikan Karakter di Pesantren." Jurnal Pendidikan Agama Islam 11, no. 2 (2017): 201-216.

Perawironegoro, Djamaluddin. "Manajemen Asrama di Pesantren." Tadbir: Jurnal Studi Manajemen Pendidikan 3, no. 2 (2019): 129-144.

Rodliyah, St. "Manajemen Pondok Pesantren Berbasis Pendidikan Karakter." Jurnal Cendekia 12, no. 2 (2014): 299-314.

Sauri, Sofyan. Nilai Kearifan Pesantren. Edited by Mohamad Zaka Al-Farisi. Bandung: Rizqi Press, 2017.

Sopidi, Sopidi. "Integrasi Modal Sosial dan Budaya dalam Pengembangan Nilai-Nilai Pendidikan Karakter di Pondok Pesantren Modern As-Sakinah Sliyeg Indramayu." Holistik 15, no. 2 (2014): 287-308. 
Sumardi, Kamin. "Potret Pendidikan Karakter di Pondok Pesantren Salafiah." Jurnal Pendidikan Karakter 0, no. 3 (2013): 280-291.

Suradi, Ahmad. "Dampak Transformasi Sistem Pendidikan Pesantren terhadap Penanaman Jiwa Keikhlasan Santri." Jurnal At-Ta'dib 13, no. 1 (2018): 49-66.

Susanto, Dedy. "Manajemen Pengembangan Sumber Daya Santri Berbasis Teknologi Tepat Guna di Pondok Pesantren." Jurnal Ilmu Dakwah 37, no. 2 (2017): 247-283.

Syafe'i, Imam. "Pondok Pesantren: Lembaga Pendidikan Pembentukan Karakter." Al-Tadzkiyyah: Jurnal Pendidikan Islam 8, no. 1 (2017): 61.

Tanshil, Sri wahyuni. "Model Pembinaan Pendidikan Karakter pada Lingkungan Pondok Pesantren dalam Membangun Kemandirian dan Disiplin Santri." Penelitian Pendidikan 13, no. 2 (2012): 1-18.

Yusup, M. "Manajemen Pendidikan Karakter Berbasis Pondok Pesantren Darussyifa Al-Fithroh Yaspida Sukabumi." Jurnal Tadbir Muwahhid 2, no. April (2018): 11-24. 